\title{
PRIMARY TUBERCULOSIS OF THE CONJUNCTIVA TREATED WITH STREPTOMYCIN AND P.A.S.*
}

BY

\author{
STELLA EADIE
}

Edinburgh

Primary tuberculosis of the conjunctiva is a rare condition, the existence of which was for long open to question. It has, however, now been shown that the disease can be produced experimentally (Igersheimer, 1922) and later reports have established its clinical occurrence. (Blevgad, 1933; Bruce and Locatcher-Khorazo, 1947).

Since the advent of antibiotics, there have been several reports of cases treated with streptomycin. In some, both local and systemic streptomycin has been used (Das Gupta and Usman, 1949; Sykowski, 1950); and in others the use of the drug has been combined with ultra-violet light therapy (Kamel, 1950), or with para-amino-salicylic acid (Wheeler and Sinclair, 1952). In all cases, however, the course of treatment has been comparatively short, and it has not always been effective in preventing caseation of the regional glands (Donegan, 1950).

\section{Case Report}

A girl, aged 15, was first seen at the Royal Infirmary, Edinburgh, on March 19, 1953.

History.-She had had a right cervical adenitis 3 weeks before the examination. After 10 days this had partially subsided, but the right conjunctiva was hyperaemic and 2 days later a swelling was seen under the right upper lid. Since then the condition had remained unchanged and the patient had felt well.

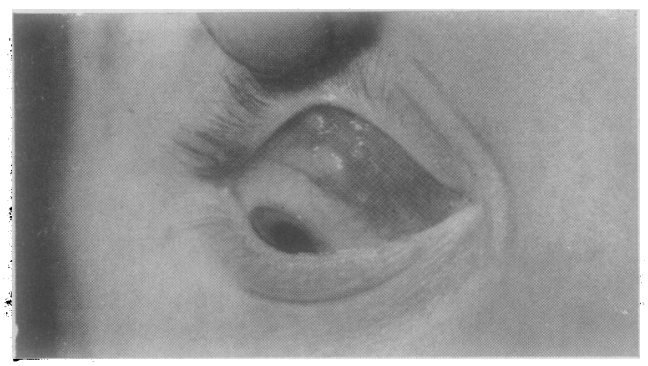

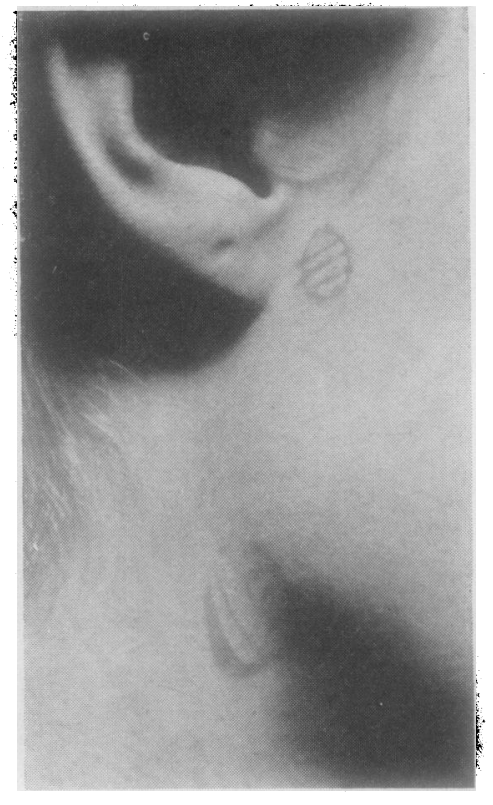

Fig. 2.-Palpable gland outlined on skin. 
Past History.-Nothing of importance.

Family History.-One brother suffered from pulmonary tuberculosis and was being nursed at home.

Examination.-The patient was a girl of average build, who appeared in good health.

Right eye.-The conjunctiva showed a follicular reaction above the tarsal plate and in the upper fornix. There was an irregular inflammatory mass extending from the limbus to the fornix, mainly on the medial side. This mass was fixed to the sclera and the surface showed small ulcerated areas (Fig. 1). The right pre-auricular and upper cervical glands were enlarged but not tender (Fig. 2). Visual acuity in the right eye was $6 / 5$, and $J 1$ unaided. Fundus normal.

Left eye.-There was no abnormality and visual acuity was $6 / 5$ and $J 1$ unaided. The fundus was normal.

She was admitted to hospital on March 21, 1953. Throughout her stay she was afebrile. Special Investigations

Mantoux Test: 1: 10,000-strongly positive.

$X$ ray of Chest: Negative.

Tissue Biopsy from Right Conjunctiva:

Pathological Report.-The tissue contains several typical tuberculous follicles. These are discrete and fairly recent with commencing central caseation in some of them. At one point several tubercles have breeched the lining epithelium and are discharging on the surface. The tubercles are accompanied by oedema and much non-specific lymphocyte and plasma-cell infiltration (Fig. 3).

Bacteriological Report.-A scanty growth of M. tuberculosis (human strain) was obtained on culture.

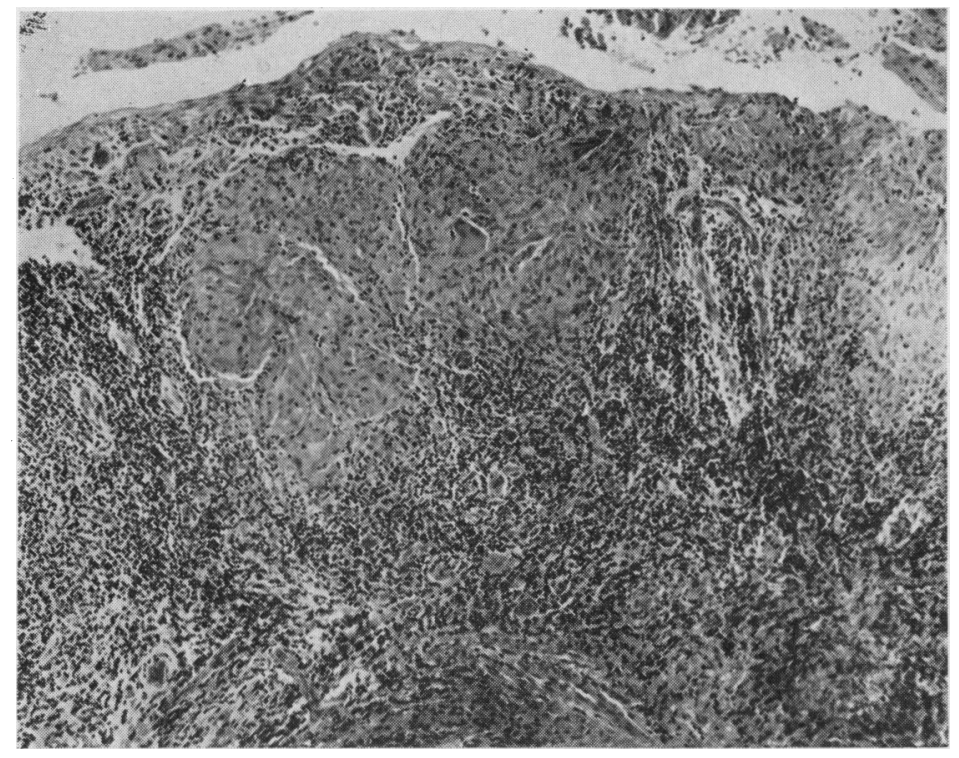

FIG. 3.-Section of tissue taken for biopsy showing tuberculous follicle formation.

Treatment.-She was given streptomycin 0.75 g. per day, and P.A.S. 15 g. per day.

On April 24, 1953, she was transferred to the Astley Ainslie Hospital where she was treated under a sanatorium régime.

In August, 1953, the streptomycin was reduced to 0.75 g. twice weekly, and in September she was discharged from hospital.

Streptomycin and P.A.S. were stopped in December, 1953. 
Progress.-May, 1953, the inflammatory mass was still present but was smaller and less congested. The pre-auricular and cervical glands were smaller.

$J u l y, 1953$, the conjunctival mass was resolving; the pre-auricular gland was just palpable, and the cervical gland was smaller.

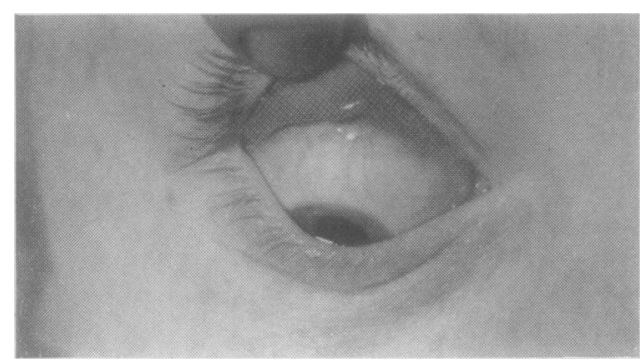

FIG. 4.-Right eye in December, 1953, showing complete resolution of inflammatory mass.
September, 1953, the conjunctiva was completely healed.

December, 1953, the eye appeared normal apart from a small scar where the biopsy had been taken (Fig. 4). A very small cervical gland could still be palpated.

\section{Summary}

A case of primary tuberculosis of the conjunctiva successfully treated by systemic streptomycin and P.A.S.

I wish to thank Dr. G. I. Scott of the Eye Department, Royal Infirmary, Edinburgh, and Professor John Crofton of the Department of Tuberculosis, University of Edinburgh, for permission to publish this case.

\section{REFERENCES}

Blegvad, O. (1933). Acta ophthal. (Kbh.)., 11, 345.

BruCe, G. M., and Locatcher-Khorazo, D. (1947). Arch. Ophthal. (Chicago), 37, 375.

Das GuPta, B. K., and Usman, M. (1949). British Journal of Ophthalmology, 33, 501.

Donegan, J. M. (1950). Amer. J. Ophthal., 33, 1117.

Igersheimer, J. (1922). Klin. Mbl. Augenheilk., 69, 226.

KAMEL, S. (1950). British Journal of Ophthalmology, 34, 322.

SyкоWSкi, P. (1950). Amer. J. Ophthal., 33, 1291.

WheELER, J. R., and SinCLAIR, S. R. (1952). Trans. ophthal. Soc. U.K., 72, 3. 